\title{
Gidya ve Poliakrilamid Uygulamalarının Farklı Tekstürdeki Toprakların Bazı Fiziksel Özellikleri Üzerine Etkileri
}

\author{
Gonca YÜCE' Tuğrul YAKUPOĞLU*2
}

'Gıda Tarım ve Hayvancılık Bakanlığı, Dulkadiroğlu İlçe Gıda Tarım ve Hayvancılık Müdürlüğü, Kahramanmaraș

Bozok Üniversitesi, Ziraat Fakültesi, Toprak Bilimi ve Bitki Besleme Bölümü, Erdoğan Akdağ Yerleșkesi, 66900, Yozgat

*Sorumlu yazar e-posta (Corresponding author e-mail): tugrul.yakupoglu@bozok.edu.tr DOI: 10.21657/topraksu.338307

\section{Öz}

Bu çalıșmada, killi ve kumlu topraklara uygulanan poliakrilamid (PAM) ve gidyanın toprakların bazı fiziksel özelliklerinde zamana bağımlı olarak meydana getirdiği değișimler incelenmiștir. Çalıșmanın amacına yönelik olarak fırın kuru ağırlık esasına göre gidya ve PAM'ın farklı doz kombinasyonları deneme konusu topraklara uygulanmıștır. Tesadüf parselleri deneme desenine göre kurgulanan çalıșma, sera koșullarında tutulan plastik saksılarda yürütülmüștür. Deneme kurulduktan sonra 4. 8. ve 12. aylarda saksılar bozularak gerekli ölçümler yapılmıștır. Toprakların fiziksel özelliklerindeki değișimi değerlendirmek için doğrusal uzama katsayısı (COLE), likit limit (LL), plastik limit (PL) ve doygun hidrolik iletkenlik $\left(K_{\text {sat }}\right)$ değerleri ölçülmüștür. Çalıșma sonucunda gerçekleștirilen varyans analizine göre ölçülen bütün değișkenler üzerine toprak çeșidi, uygulama ve örnekleme zamanının etkisi önemli $(p<0,001)$ bulunmuștur. Toprakların COLE değerleri uygulama dozlarının artıșıyla azalma gösterirken, $\mathrm{K}_{\text {sat’ }^{\prime}} \mathrm{LL}$ ve PL değerleri uygulama dozlarının yükselmesiyle artıș göstermiștir. Bu fiziksel parametrelerin zamana bağımlı değișimleri incelendiğinde $\mathrm{K}_{\text {sat' }} \mathrm{LL}$ ve PL azalırken, COLE'nin artıș gösterdiği bulgusu elde edilmiștir. Değișkenlere ait verilere uygulanan Duncan testlerine $(\alpha=0,05)$ göre COLE'u azaltmada en etkili uygulamalar aralarında istatistiksel olarak fark bulunmayan birinci doz gidyanın (G1) PAM ile birlikte uygulanması ([G1+PAM]) ve ikinci doz gidyanın (G2) PAM ile birlikte uygulanması ([G2+PAM]) olarak bulunmuștur. LL'i artırmada en etkin uygulama [G2+PAM] iken PL'i ve Ksat'ı artırmada ise aralarında istatistiksel anlamda fark bulunmayan G2, [G1+PAM] ve [G2+PAM] uygulamaları en etkili olarak bulunmuștur. Bu sonuçlar, saksılardaki organik madde miktarının zamana bağımlı olarak değișimine atfedilebilir ve organik maddenin toprak hidrolojisindeki etkinliği, toprak su bütçesinin fiziksel özelliklere etki etmesi ve PAM'ın agregatların stabilitesini artırmadaki etkinliği ile açıklanabilir.

Anahtar Kelimeler: Atterberg limitleri, COLE, hidrolik iletkenlik, toprak düzenleyiciler

\section{Effects of Gyttja and Polyacrylamide Applications on Some Physical Properties of Soils with Different Texture}

\footnotetext{
Abstract

In this study, polyacrylamide (PAM) and gyttja applied to clayey and sandy soils caused by timedependent changes in some physical properties were investigated. For the purpose of the study, various dose combinations of gyttja and PAM were applied to soils by the oven dry weight basis. Study constructed according to a randomized complete block experimental design was carried out in plastic pots kept under greenhouse conditions. 4, 8 and 12 months after the experiment establishment, pots were deteriorated and necessary measurements realized. In order to assess the changes in physical properties of soils, coefficient of linear extensibility (COLE), liquid limit (LL), plastic limit (PL) and saturated hydraulic conductivity $\left(\mathrm{K}_{\text {sat }}\right)$ values were measured. According to ANOVA test results, effects of soil,
} 
application, and sampling time on measured all variables were found as significant $(p<0.001)$. While COLE values of soils decreased with rising application doses, $K_{\text {sat' }} L L$ and PL values increased. When analyzing the time-dependent changes of these physical parameters, it was obtain a finding that $\mathrm{K}_{\text {sat' }^{\prime}} \mathrm{LL}$ and PL decreased but COLE increased. According to Duncan test ( $\alpha=0.05)$ results, the most effective applications to decrease in COLE were first dose gyttja + PAM ([G1+PAM]) and second dose gyttja + PAM ([G2+PAM]) that there is no statistically difference between these. The most effective application to increase in $L L$ was [G2+PAM] and the most effective applications to increase in $P L$ and $K_{\text {sat }}$ were G2, [G1+PAM] and [G2+PAM] that two applications was same, statistically. These results attributed to changes of organic matter content as time-depending in pots and argued and described frame of these changes. frame.

\section{Key Words: Atterberg limits, COLE, hydraulic conductivity, soil conditioners}

\section{Giriș}

Toprak organik maddesinin, toprakların fiziksel özellikleri üzerine doğrudan ve dolaylı etkileri bilinmektedir. Toprakların fiziksel özelliklerinin optimum seviyede olması, fiziksel verimliliklerinin yüksek olduğu anlamına gelmektedir. Özellikle toprakta suyun tutulması ve hareketi, toprakların șișme-büzülme özellikleri ve kıvam indeks değerleri tarım topraklarında büyük öneme sahiptir. Bu özellikler toprak organik maddesi ile doğrudan ilișkilidir.

Yaklașık 3000 yıldır tarım yapılan ülkemiz toprakları sahip olduğu topoğrafik yapı, iklim koșulları ve hatalı kullanımlara bağlı olarak özellikle organik maddece yoksullașmıștır. Türkiye toprakları organik madde bakımından belirli alanlar dıșında genellikle fakirdir. Türkiye'de birçok bölgede, özellikle Orta Anadolu bölgesi topraklarının organik madde içerikleri \% 2'nin hatta yer yer \% l'in altına düșmüștür (Gezgin vd., 2001). Toprak ekolojisi göz önünde bulundurulduğunda, bitkilerin gelișimlerini devam ettirebilmeleri için tarım topraklarında verimliliğin artırıması veya mevcut verimlilik potansiyelinin korunması ve topraklardan kaldırılan veya çeșitli yollarla kayba uğrayan bitki besin elementlerinin çevre ile barıșık șekilde yeniden bu topraklara kazandırılması gerekmektedir (Taban vd., 2005). Bu anlamda organik atıkların düzenleyici olarak topraklara uygulanması akılcı bir çözüm yoludur. Bu amacı yerine getirmek için uygun olan organik kökenli toprak düzenleyicilerin özellikle tarımsal sanayi atıklarının kullanılması, doğal kaynakların sürdürülebilirliği ve sürdürülebilir bir tarımsal üretim hedeflerine hizmet etmektedir (Bhuiyan, 2001). Bu nedenle organik madde yönünden genelde fakir olan ülkemiz tarım arazilerinde organik atıkların topraklara düzenleyici olarak uygulanması daha da önem kazanmaktadır.
Toprakların organik madde içeriği enerji sağlama bașta olmak üzere toprak fonksiyonlarının birçoğu için gereklidir (Lal ve Kimble, 1997). Özellikle toprakların organik madde içeriklerinin korunması ve arttırılması sürdürülebilir tarımda büyük önem tașımaktadır. Yoğun tarımsal faaliyetler sonucunda azalan organik madde intiyacının karșılanması için toprağa organik madde ilavesi gerekmektedir. Organik düzenleyici olarak kullanılan kaynaklar ahır gübresi bașta olmak üzere pirina, leonardit, çay fabrikasyon atığı, fındık zurufu, tütün fabrikasyon atığı, çeltik kavuzu, biyokatı ve bunların kompostlanmıș șekilleridir. Bu kaynaklardan birisi de toprağın fiziksel, kimyasal ve biyolojik özelliklerini iyileștirebilecek nitelikte olan gidya materyalidir. Gidya, yüksek oranda karbon ve humik asitler içeren, kömür düzeyine ulașmamıș doğal bir organik materyaldir.

Fiziksel özellikleri bakımından bozulmuș topraklarda yapıyı iyileștirmek için üst toprak içerisine organik atıkların karıștırılması en yaygın yol olarak izlenmektedir. Ancak toprakların ıslahında fazla miktarda organik girdiye intiyaç duyulması ve söz konusu organik madde kaynağının topraktaki ayrıșma sürecinin uzun olması bu alanda organik kökenli sentetik toprak düzenleyicilerinin alternatif kullanım olanaklarının araștırılmasına yol açmıștır. $\mathrm{Bu}$ alanda poliakrilamid (PAM) kullanımı yoğun olarak araștırılmaya bașlanmıștır. Bu konuda yapılan çalıșmalarda, sentetik polimerlerin toprak yüzeyine çok düșük dozlarda uygulanmasının bile agregat stabilitesini artırma bakımından önemli pozitif etkiler yapabileceği genel bir sonuç olarak vurgulanmaktadır (Bryan, 1992; Sojka ve Lentz, 1994; Imbufe vd., 2005).

Bu çalıșmada, organik düzenleyici olarak kullanılan gidyanın, tek bașına ve PAM ile kombine edilerek uygulanan farklı dozlarının, toprakların 
Atterberg limitleri, doğrusal uzama katsayıları ve hidrolik iletkenlik özellikleri üzerine etkileri araștırılmıștır.

\section{MATERYAL VE YÖNTEM}

\section{Deneme Topraklarının Alındığı Yerler ve İklim-Toprak Özellikleri}

Araștırmada kullanılan kumlu toprak örneği Kahramanmaraș Doğu Akdeniz Geçit Kușağı Tarımsal Araștırma Müdürlüğü uygulama arazilerinden, killi toprak örneği ise Kahramanmaraș Sütçü İmam Üniversitesi Avșar Kampüsü arazilerinden alınmıștır. Deneme konusu toprakların bazı kimyasal ve fiziksel özellikleri sırasıyla Çizelge 1 ve 2'de verilmiștir.

\section{Denemede Kullanılan Organik ve Sentetik Düzenleyiciler}

Bu çalıșmada organik düzenleyici materyal olarak gidya, düzenleyici polimer olarak ise poliakrilamid (PAM) kullanılmıștır. Afșin Elbistan Termik santralinden temin edilen ve denemede kullanılan gidya, bazı kimyasal özellikleri, kimyasal kompozisyonu ve bazı fiziksel özellikleri Yakupoğlu vd., (2013)'de tanımlanan materyaldir.

\section{Denemenin Kurulması ve Yürütülmesi}

Denemeye konu olan topraklar ahșap tokmakla dövülerek $2 \mathrm{~mm}$ 'lik elekten geçirilmiș ve 13,5 cm boyunda, $9 \mathrm{~cm}$ çapında plastik saksılara konulmuștur. Hazırlanan topraklara gidya ve PAM Çizelge 3'de verilen kombinasyonlarda kuru ağırlık esasına göre (w/W) uygulanmıștır. Gidya materyali uygulanmadan önce 0,5 mm'lik elekten geçirilmiștir. PAM ise saf suda eritildikten sonra bir el püskürtücüsü yardımıyla uygulanmıștır. Verilen kombinasyonlar, farklı zamanlarda bozulmak üzere üç grup halinde hazırlanmıștır. Saksı denemesi 01.06.2013 tarihinde kurulmustur. Hazırlanan denet ve karıșım saksıları, 12 ay süre ile sera koșullarında tutulmuș ve saksılardaki nem tarla kapasitesinin yaklașık yarısına kadar düștüğünde yine tarla kapasitesine ulașıncaya kadar sulanmıștır. Uygulamaların toprakların fiziksel özelliklerinde zamana bağlı olarak meydana getirdiği değișimi belirlemek için her 4 ayda bir uygulama grupları bozulmuș ve ilgili analizler yapılmıștır.

\section{Toprak Analizleri}

Doğrusal uzama katsayısı (COLE), doygunluktan biraz daha az nem düzeyinde

Çizelge 1. Deneme konusu toprakların bazı kimyasal analiz sonuçları

Table 1. Some chemical analyses results of experiment soils

\begin{tabular}{|c|c|c|c|c|c|c|c|c|c|}
\hline Toprak & $\mathrm{pH}$ & $\begin{array}{l}\mathrm{EC}_{25^{\circ} \mathrm{C}} \\
\mathrm{dS} \mathrm{m}^{-1}\end{array}$ & $\begin{array}{l}\mathrm{CaCO}^{3} \\
\mathrm{~g} \mathrm{~kg}^{-1}\end{array}$ & $\begin{array}{c}\mathrm{OC} \\
\mathrm{g} \mathrm{kg}^{-1}\end{array}$ & $\begin{array}{c}\text { KDK } \\
\mathrm{cmol}_{\mathrm{C}}(+) \mathrm{kg}^{-1}\end{array}$ & $\begin{array}{l}\mathrm{Ca}++ \\
\mu \mathrm{g} \mathrm{g}^{-1} \\
\end{array}$ & $\begin{array}{l}\mathrm{Mg++} \\
\mu g^{-1} \\
\end{array}$ & $\begin{array}{c}\mathrm{K}+ \\
\mu \mathrm{g} \mathrm{g}^{-1}\end{array}$ & $\begin{array}{l}\mathrm{Na}+ \\
\mu g g^{-1}\end{array}$ \\
\hline Mollic Xerofluvent & 8,1 & 2,53 & 67 & 13,2 & 38 & 12030 & 871 & 116 & 60 \\
\hline Typic Xerorthent & 8,5 & 1,90 & 181 & 10,1 & 17 & 7915 & 427 & 127 & 57 \\
\hline
\end{tabular}

pH ve EC saturasyon çamurunda ölçülmüștür. Değișebilir katyonların, amonyum asetatla ekstrakte edilebilir formları verilmiștir

Çizelge 2. Deneme konusu toprakların bazı fiziksel analiz sonuçları

Table 2. Some physical analyses results of experiment soils

\begin{tabular}{|c|c|c|c|c|c|c|c|c|c|}
\hline Toprak & $\begin{array}{c}\text { Kil } \\
\mathrm{g} \mathrm{kg}^{-1}\end{array}$ & $\begin{array}{l}\text { *Silt } \\
\text { gkg }^{-1}\end{array}$ & $\begin{array}{l}\text { Kum } \\
\mathrm{gkg}^{-1}\end{array}$ & $\begin{array}{c}\text { Tekstür } \\
\text { sınıfı }\end{array}$ & $\begin{array}{c}\mathrm{HA} \\
\mathrm{Mgm}^{-3}\end{array}$ & $\begin{array}{c}\text { SAT } \\
\mathrm{cm}^{3} \mathrm{~cm}^{-3}\end{array}$ & $\begin{array}{c}\text { TK } \\
\mathrm{cm}^{3} \mathrm{~cm}^{-3} \\
\end{array}$ & $\begin{array}{c}\text { DSN } \\
\mathrm{cm}^{3} \mathrm{~cm}^{-3} \\
\end{array}$ & $\begin{array}{c}\mathrm{YS} \\
\mathrm{cm}^{3} \mathrm{~cm}^{-3} \\
\end{array}$ \\
\hline Mollic Xerofluvent & 548 & 228 & 224 & C & 1,30 & 0,65 & 0,44 & 0,33 & 0,11 \\
\hline Typic Xerorthent & 291 & 192 & 517 & SCL & 1,36 & 0,40 & 0,31 & 0,19 & 0,12 \\
\hline
\end{tabular}

*Parçacık büyüklüğü belirlenirken USDA ölçütleri esas alınmıștır. HA: Hacim ağırlığı, Ksat: Sature hidrolik iletkenlik, SAT: Saturasyon yüzdesi, TK: Tarla kapasitesi, DSN: Devamlı solma noktası, YS: Yarayıșlı su

Çizelge 3. Kullanılan düzenleyicilerin uygulama dozları

Table 3. Application doses of conditioners

\begin{tabular}{ll}
\hline Notasyon & Uygulama \\
\hline Kontrol & 1500'er gram hava kuru toprak \\
G1 & FKA üzerinde $\% 3$ OM içerecek kadar gidya \\
G2 & FKA üzerinde $\% 6$ OM içerecek kadar gidya \\
G1 + PAM & G1 uygulanan saksıya \% 0,005 PAM \\
G2 + PAM & G2 uygulanan saksıya \% 0,005 PAM \\
\hline
\end{tabular}


iken balçıklaștırılan topraktan, bir șırınga yardımı ile elde edilen 1 cm çapında ve 6-10 cm uzunluğundaki çubukların, vazelin sürülmüș bir yüzey üzerinde 48 saat süre ile atmosfer koșullarında kurutulduktan sonra uzunluklarının ölçülmesi ve ıslak çubuk ve kuru çubuk arasındaki uzunluk farkının, kuru çubuk uzunluğuna oranlanmasıyla hesaplanmıștır (Schafer and Singer, 1976). Toprakların likit limit (LL) değerleri Casagrande aleti kullanılarak, plastik limit (PL) değerleri ise nemli toprağın 3 mm'lik iplikçiler haline getirilmesinden sonra dağımaya bașladığı anda sahip olduğu nem miktarına göre belirlenmiștir (Sowers, 1965). Toprakların doygun koșullardaki hidrolik iletkenlik değerleri ( $\left.\mathrm{K}_{\text {sat }}\right)$ Darcy yasası uyarınca laboratuvar koșullarında Mariotte düzeneği kurularak Ölçülmüștür (Özdemir, 1998).

\section{İstatistiksel Analizler}

İstatistiksel analizler SPSS bilgisayar programında yapılmıștır. Ölçülen değișkenler üzerine istatistiksel konuların etkili olup olmadığının araștırılmasında varyans analizinden yararlanılmıștır. Varyans analizi sonucunda $F$ değeri önemli bulunan değișkenler üzerine konuların etkinliğini incelemek için Duncan testinden faydalanıImıștır (Yurtseven, 1984).

\section{BULGULAR VE TARTIȘMA}

\section{Gidya ve PAM'ın Toprakların Doğrusal Uzama Katsayıları (COLE) Üzerine Etkileri}

Uygulanan düzenleyicilerin deneme konusu toprakların COLE değerlerinde kontrole göre sağladığı değișimler Șekil 1'de sunulmuștur. Adı geçen șekle göre Gidya ve PAM uygulamaları toprakların COLE değerlerini uygulama dozlarının artmasıyla azaltmıș ancak zamana bağlı olarak toprakların COLE değerleri artma eğilimi göstermiștir. Örnekleme zamanları dikkate alındığında COLE en düșük kumlu toprakta 4. ayda bozulan saksılardan alınan örneklerde belirlenmiștir. 8. ve 12. aylarda COLE'nin örnekleme zamanının uzamasına bağlı olarak arttığı belirlenmiștir. En düșük cole değeri $(0,050)$ kumlu toprağa yüksek doz gidya ve PAM'ın birlikte uygulandığı (G2+PAM) saksıda 4. ay örneklemesinde ölçülmüștür. En yüksek COLE $(\% 0,169)$ ise killi toprağın kontrol uygulaması için belirlenmiștir. ANOVA sonuçlarına COLE değerlerine uygulama dozunun, toprak çeșidinin ve örnekleme zamanının etkisi istatistiksel açıdan $p$ $<0.001$ seviyesinde önemli bulunmuștur.

Çizelge 4. ve 5'de COLE değișkeni için sırasıyla uygulamalara ve zamana ait Duncan test sonuçları

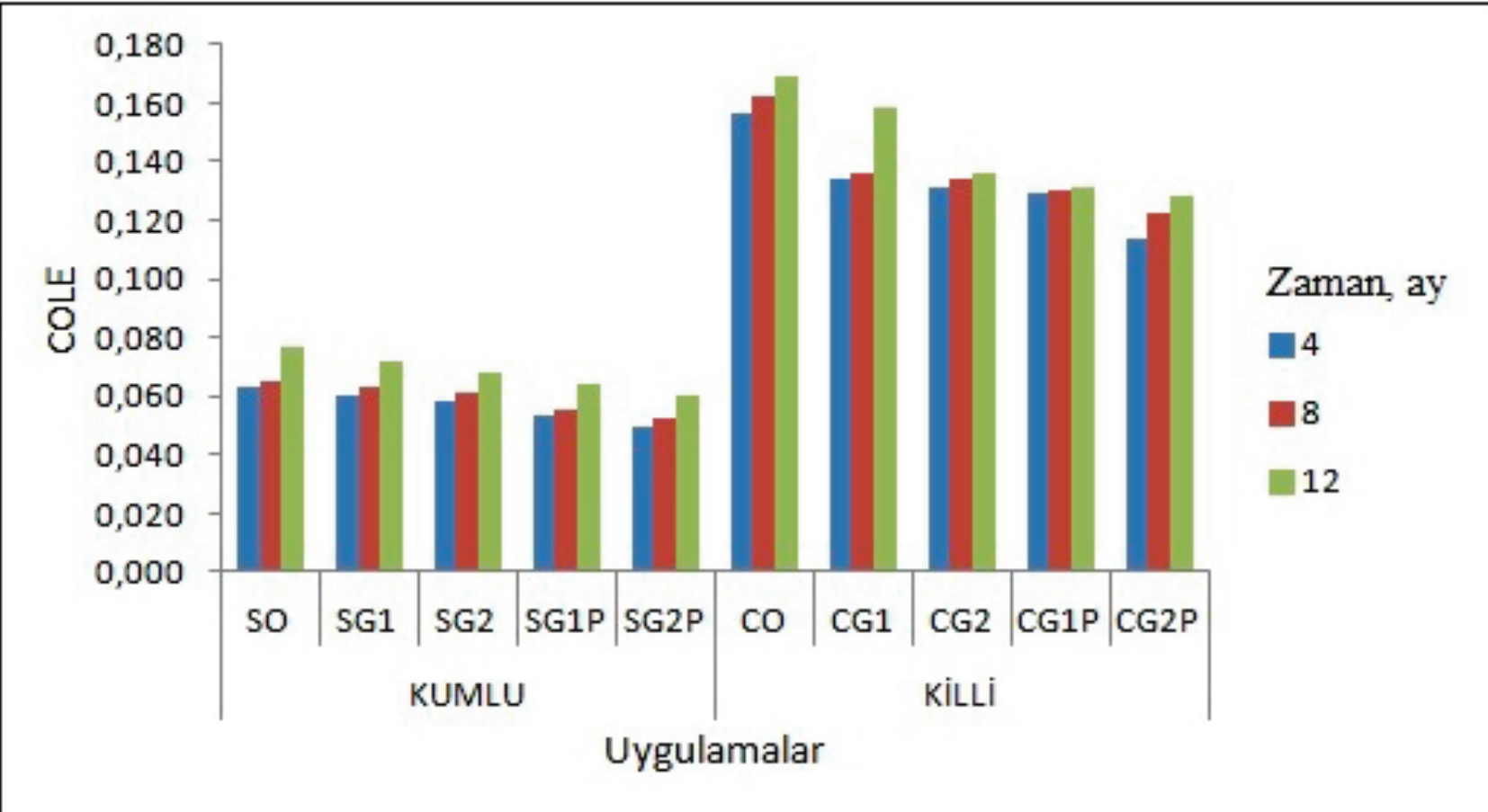

Șekil 1. Uygulamaların toprakların Cole kapsamlarında meydana getirdiği değișimler (So: Kumlu toprak kontrolü, C0: Killi toprak kontrolü, G1: Gidya birinci doz uygulaması, G2: Gidya ikinci doz uygulaması, G1P: [G1 +PAM], G2P: [G2+PAM])

Figure 1. Changes in COLE values of soils with applications (SO: Control for sandy soil, Co: Control for clayey soil, G1: First gyttja dose application, Second gyttja dose application, GIP: [G 1+PAM], G2P: [G2+PAM]) 
Çizelge 4. COLE değișkeni için uygulamalara ait Duncan testi sonucu

Table 4. Duncan test results for COLE from applications

\begin{tabular}{|c|c|c|c|c|}
\hline \multirow{2}{*}{ Uygulama } & \multicolumn{4}{|c|}{ COLE (Alt küme) } \\
\hline & 1 & 2 & 3 & 4 \\
\hline G2+PAM & $0,0877 d$ & & & \\
\hline G1+PAM & $0,0937 \mathrm{~cd}$ & $0,0937 \mathrm{~cd}$ & & \\
\hline $\mathrm{G} 2$ & & $0,0980 \mathrm{bc}$ & $0,0980 \mathrm{bc}$ & \\
\hline G1 & & & $0,1038 b$ & \\
\hline Kontrol & & & & $0,1155 a$ \\
\hline Sig. & 0,108 & 239 &, 118 & 1,000 \\
\hline $\mathrm{HKO}=3,85 \mathrm{E}-005$. & 0,05 & & & \\
\hline
\end{tabular}

Çizelge 5. COLE değișkeni için örnekleme zamanına ait Duncan testi sonucu

Table 5. Duncan test results for COLE from applications

\begin{tabular}{|c|c|c|}
\hline \multirow{2}{*}{ Zaman } & \multicolumn{2}{|c|}{ COLE (Alt küme) } \\
\hline & \multirow{2}{*}{$\frac{1}{0,0948 b}$} & \multirow[t]{2}{*}{2} \\
\hline 4.ay & & \\
\hline 8.ay & $0,0981 \mathrm{~b}$ & \\
\hline 12.ay & & $0,1063 a$ \\
\hline Sig. & 0,247 & 1,000 \\
\hline $\mathrm{HKO}=3,85 \mathrm{E}-005 \quad \alpha=$ & & \\
\hline
\end{tabular}

verilmiștir. Uygulamaların COLE üzerine etkinlikleri incelendiğinde ortalama en yüksek COLE değerinin kontrol saksıları için hesaplandığı, COLE'yi azaltmada en etkili uygulamaların aralarında istatistiksel fark bulunmayan G1+PAM ve G2+PAM uygulamaları olduğu görülmüștür. Çizelge 5'e göre 4. 8. aylara ait ortalama COLE değerleri istatistiksel bakımdan farklılık arz etmemiș ancak 12. ay örneklemesi ilk iki örnekleme zamanının ortalamalarından farkı olmak üzere en yüksek bulunmuștur. Bu bulgular, organik düzenleyici uygulamalarının COLE değerlerini düșürdüğünü ifade eden bașka bir çalıșmanın (Yakupoğlu ve Özdemir, 2006) sonuçları ile örtüșmektedir.

\section{Gidya ve PAM'ın Toprakların Likit Limit (LL) Değerleri Üzerine Etkileri}

Uygulanan düzenleyicilerin deneme konusu toprakların LL değerlerinde kontrole göre sağladığı değișimler Șekil Z'de sunulmuștur. Söz konusu șekle göre gidya ve PAM uygulamaları toprakların LL değerlerini artırmıș ancak zamana bağlı olarak toprakların LL değerlerinin azaldığı sonucuna ulașılmıștır. Örnekleme zamanları dikkate alındığında LLenyüksek 4. ayda bozulan saksılardan alınan örneklerde belirlenmiștir. 8. ve 12. aylarda LL azaldığı belirlenmiștir. En düșük LL değeri $(\%$ 25,5) herhangi bir uygulama yapılmayan kumlu toprakta 12. ayda, en yüksek $L L$ değeri ise $(\% 54,0)$ killi toprağa [G2+PAM] uygulamasının yapııdığı saksıda 4.ay örneklemesinde belirlenmiștir. Yüksek doz gidyanın PAM ile birlikte uygulandığında özellikle 8. ve 12. aylarda toprağın $L L$ değerindeki azalmanın daha az olduğu görülmüștür.

Likit limit değișkenine ait ANOVA sonuçlarına göre toprakların LL değerlerinde meydana gelen değișim uygulama çeșidinden, örnekleme zamanından ve toprak çeșidinden etkilenmiștir ( $\mathrm{P}$ $<0,001)$.

Çizelge 6. ve 7'de LL değișkeni için sırasıyla uygulamalara ve zamana ait Duncan test sonuçları verilmiștir. Uygulamaların LL üzerine etkinlikleri incelendiğinde $\mathrm{Gl}$ ve $\mathrm{G} 2$ uygulamasının istatistiksel bakımdan aynı olduğu, en düșük LL kontrol uygulamasında belirlenirken en yüksek LL'nin [G2+PAM] uygulaması ile elde edildiği sonucuna ulașılmıștır. Diğer taraftan üç örnekleme zamanında yapılan LL ölçümlerine ait ortalamalar birbirinden farklı bulunmuș, en yüksek LL 4. ay, en düșük LL ise 12. ay örneklemeleri için belirlenmiștir.

Likit limit değerleri toprakların fiziksel ve kimyasal özelliklerine bağlı olarak farklılık gösterebilmekte, kohezyonsuz topraklarda bu değer değeri \% 20'nin altına düșebilmektedir (Head, 1984). Smith vd., (1985) tarafından yürütülen bir çalıșmada, toprakların organik madde kapsamları ile LL 


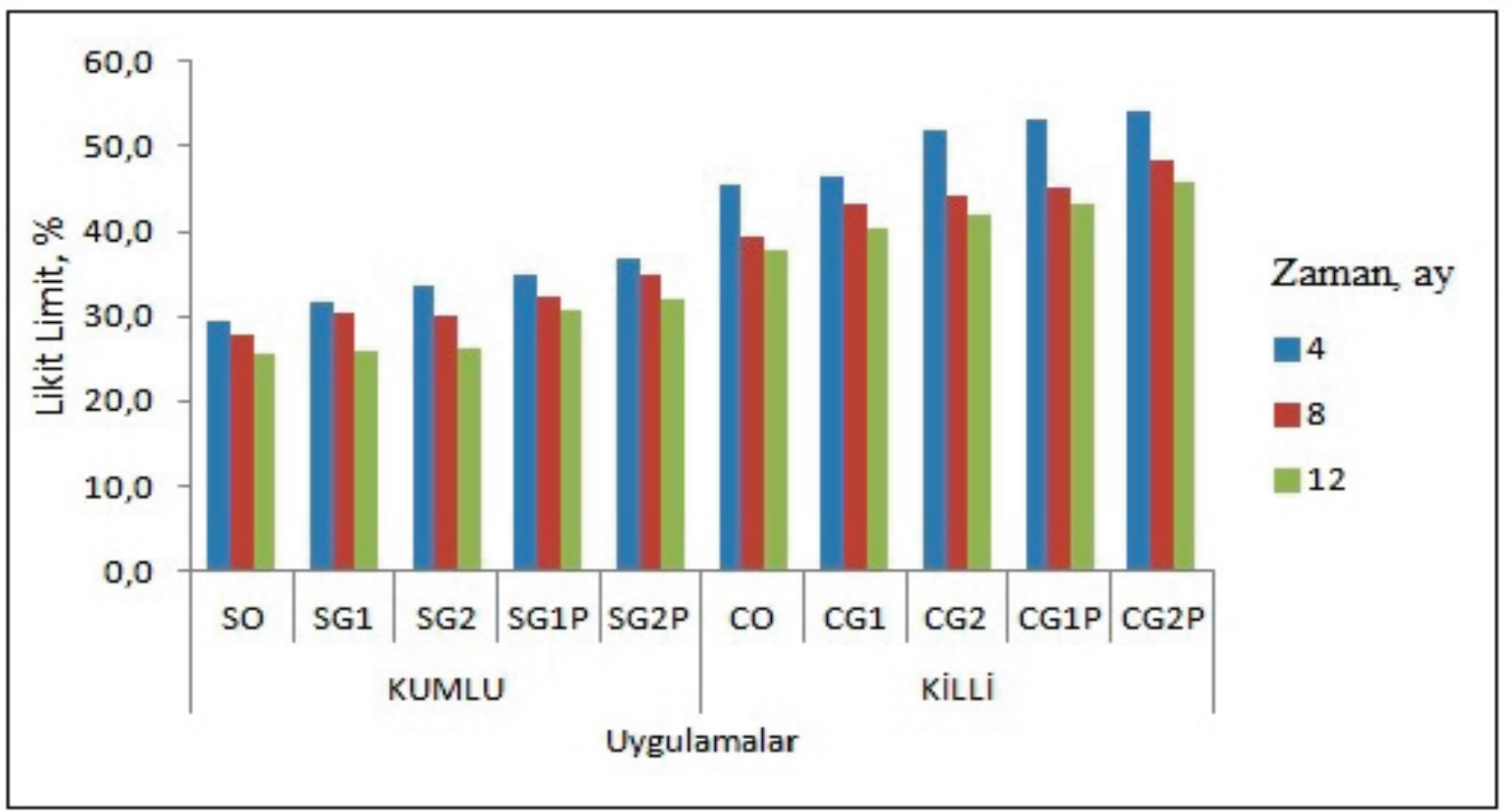

Șekil 2. Uygulamaların toprakların Likit limit kapsamlarında meydana getirdiği değișimler (SO: Kumlu toprak kontrolü, C0: Killi toprak kontrolü, G1: Gidya birinci doz uygulaması, G2: Gidya ikinci doz uygulaması, G1P: [G1+PAM], G2P: [G2+PAM])

Figure 2. Changes in liquid limit values of soils with applications (SO: Control for sandy soil, CO: Control for clayey soil, G 1: First gyttja dose application, Second gyttja dose application, GIP: [G 1+PAM], G2P: [G2+PAM])

değerleri arasında önemli istatistiksel ilișkiler elde edilmiștir. Farklı organik atıkların toprakların kıvam limitleri üzerine etkilerini araștırmak amacıyla yürütülen bașka bir çalıșmada (Gülser ve Candemir,
2004) organik atıkların uygulama miktarların artmasıyla LL değerlerinin artığı açıklanmıștır. Bu çalıșmadan elde edilen bulgular sıralanan literatürde verilen bilgilerle örtüșmektedir.

Çizelge 6. Likit limit değișkeni için uygulamalara ait Duncan testi sonucu

Table $\mathbf{6}$. Duncan test results for LL from applications

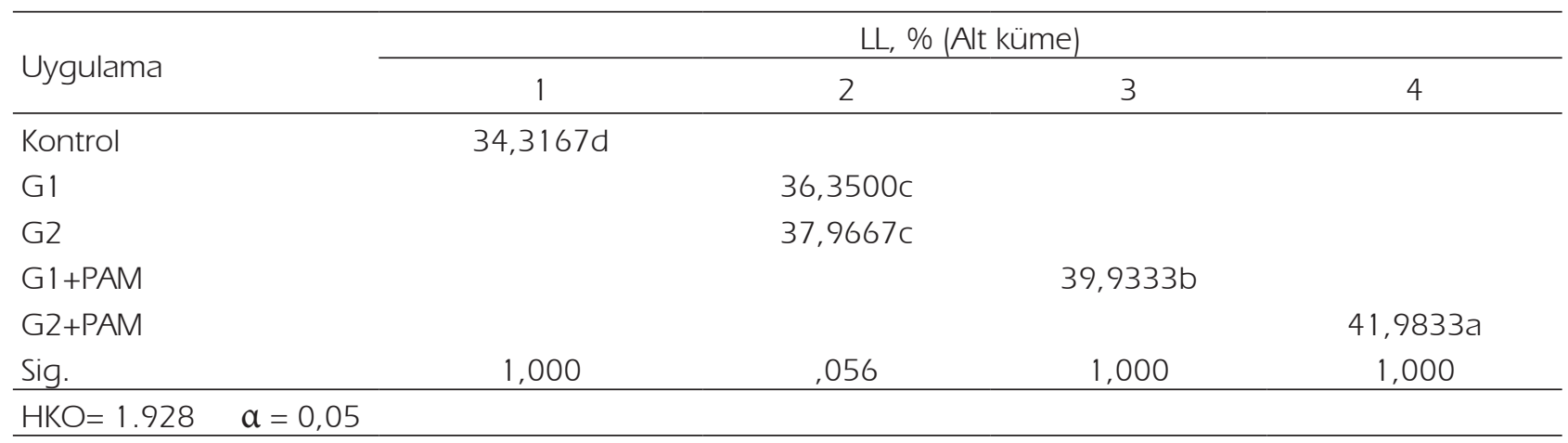

Çizelge 7. Likit limit değișkeni için örnekleme zamanına ait Duncan testi sonucu

Table 7. Duncan test results for $L L$ from sampling time

\begin{tabular}{|c|c|c|}
\hline \multirow{2}{*}{ Zaman } & \multicolumn{2}{|c|}{ LL, \% (Alt küme) } \\
\hline & 1 & 2 \\
\hline 12.ay & $34,9500 c$ & \\
\hline 8.ay & & $37,6200 \mathrm{~b}$ \\
\hline 4.ay & & \\
\hline Sig. & 1,000 & 1,000 \\
\hline
\end{tabular}




\section{Gidya ve PAM'ın Toprakların Plastik Limit (PL) Değerleri Üzerine Etkileri}

Düzenleyici olarak kullanılan malzemenin deneme konusu toprakların PL değerlerinde kontrole göre meydana getirdiği değișimler Șekil 3'de sunulmuștur. Șekil 3'e göre gidya ve PAM uygulamaları toprakların PL kapsamlarını artırmıș ancak zamana bağlı olarak toprakların PL kapsamlarının azaldığı görülmüștür. Örnekleme zamanları dikkate alındığında PL en yüksek 4. ayda bozulan saksılardan alınan örneklerde belirlenmiștir. 8. ve 12. aylarda PL değerlerinin azaldığı belirlenmiștir. En yüksek PL değeri \% 47,2 ile killi toprağa G2+PAM uygulamasının yapıldığı saksıda 4.ay örneklemesinde belirlenmiștir. En düșük PL değeri ise $(\%$ 15,1) kumlu toprağın kontrol saksısında belirlenmiștir. Genel olarak kumlu toprakta PL değerleri killi topraktan daha düșük bulunmuștur. Diğer taraftan her iki toprakta da uygulanan gidya dozunun artıșına paralel olarak örnekleme gruplarının (4, 8 ve 12 . aylar) kendi içerisinde PL değerlerinin arttığı tespit edilmiștir. Yüksek doz gidyanın PAM ile birlikte uygulandığında özellikle 4. aylarda toprağın PL bütçesine daha fazla katkı sağladığı görülmüștür.

Plastik limit değișkenine ait varyans analizi sonuçlarına göre toprakların PL değerlerinde meydana gelen değișime örnekleme zamanının, uygulama dozunun ve toprak çeșidinin etkisi istatistiksel olarak önemli $(p<0,001)$ bulunmuștur.

Çizelge 8 ve 9'da PL değișkeni için sırasıyla uygulamalara ve zamana ait Duncan test sonuçları verilmiștir. Uygulamaların PL üzerine etkinlikleri incelendiğinde, en düșük PL'nin aralarında istatistiksel olarak fark bulunmayan kontrol ve G1 uygulaması yapılan saksılarda ölçüldüğü en yüksek PL'nin ise istatistiksel bakımdan aynı olan, G2, G1+PAM ve G2+PAM uygulamalarının yapıldığı saksılar için belirlendiği sonucuna ulașılmıștır. Çizelge 9.'a göre PL en yüksek 4. aya, en düșük ise 12. aya ait örneklerde tespit edilmiștir. Her üç örnekleme zamanı da PL değeri üzerine etkinlikleri bakımından birbirinden farklı bulunmuștur.

Munsuz ve Akyıldız (1979), Afșin-Elbistan bölgesi linyit kömürü havzasından çıkartılan gidya materyalinin, bu bölge tarım topraklarının fiziksel özellikleri üzerine etkilerini inceledikleri bir laboratuvar çalıșmasında, gidya ilavesinin killi, tınlı ve killi-tınlı bünyedeki toprakların kıvam ve limit değerlerini yükselttiği belirlemiștir. Adı geçen bilim adamlarının sonuçlarını doğrular nitelikte olacak șekilde, bu çalıșmanın sonuçları da Afșin-Elbistan linyit havzasından çıkarılan gidyanın toprak kıvım limiti değerlerini yükselttiğini göstertmektedir.

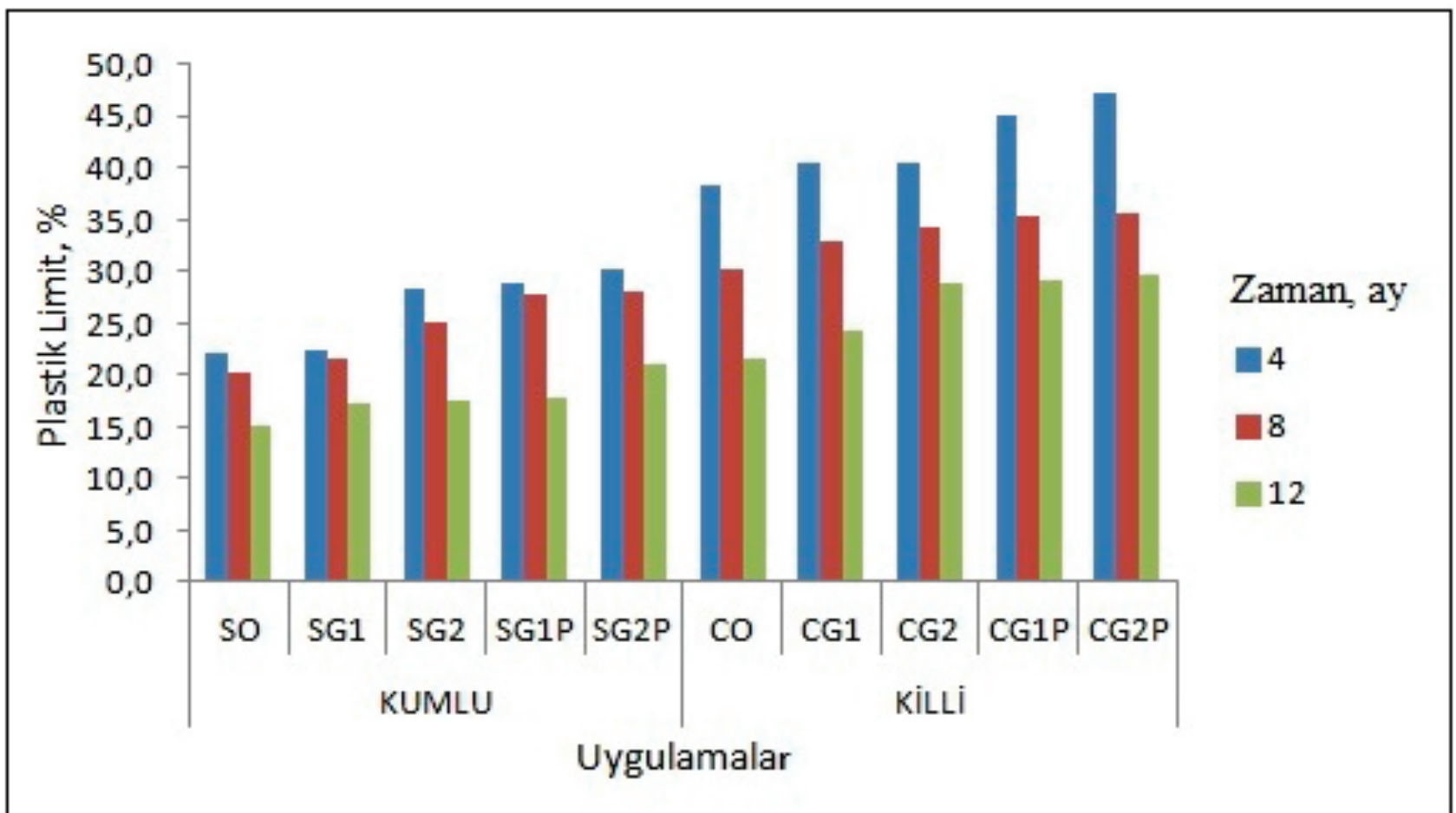

Șekil 3. Uygulamaların toprakların Plastik limit kapsamlarında meydana getirdiği değișimler (SO: Kumlu toprak kontrolü, C0: Killi toprak kontrolü, G1: Gidya birinci doz uygulaması, G2: Gidya ikinci doz uygulaması, G1 P: [G1+PAM], G2P: [G2+PAM])

Figure 3. Changes in plastic limit values of soils with applications (SO: Control for sandy soil, C0: Control for clayey soil, G1: First gyttja dose application, Second gyttja dose application, GIP: [G1+PAM], G2P: [G2+PAM]) 
Çizelge 8. Likit limit değișkeni için örnekleme zamanına ait Duncan testi sonucu

Table 8. Duncan test results for $L L$ from sampling time

\begin{tabular}{|c|c|c|c|}
\hline \multirow{2}{*}{ Uygulama } & \multicolumn{3}{|c|}{ Plastik limit, \% (Alt küme) } \\
\hline & 1 & 2 & 3 \\
\hline Kontrol & $24,5667 c$ & & \\
\hline G1 & $26,4833 \mathrm{bc}$ & $26,4833 \mathrm{bc}$ & \\
\hline G2 & & 29, $1667 a b$ & $29,1667 a b$ \\
\hline G1+PAM & & & 30,6833a \\
\hline G2+PAM & & & $31,9500 a$ \\
\hline Sig. & 0,162 & 0,055 & 0,058 \\
\hline $\mathrm{HKO}=5,261$ & & & \\
\hline
\end{tabular}

Çizelge 9. Plastik limit değișkeni için örnekleme zamanına ait Duncan testi sonucu

Table 9. Duncan test results for PL from sampling time

\begin{tabular}{|c|c|c|c|c|}
\hline \multirow{2}{*}{\multicolumn{2}{|c|}{ Zaman }} & \multicolumn{3}{|c|}{ Plastik limit, \% (Alt küme) } \\
\hline & & 1 & 2 & 3 \\
\hline 12. ay & & $22,2300 c$ & & \\
\hline 8. ay & & & $29,1100 \mathrm{~b}$ & \\
\hline 4. ay & & & & 34,3700a \\
\hline Sig. & & 1,000 & 1,000 & 1,000 \\
\hline $\mathrm{HKO}=5,261$ & $a=0,05$ & & & \\
\hline
\end{tabular}

Gidya ve PAM'ın Doygun Koșullarda Toprak Hidrolik İletkenliği $\left(K_{\text {sat }}\right)$ Üzerine Etkileri

Uygulanan

düzenleyicilerin

deneme topraklarında hidrolik iletkenlik değișkenini kontrole göre ne șekilde değiștirdiği Șekil 4'de sunulmuștur. Söz konusu șekilden, gidya ve PAM uygulamalarının toprakların $\mathrm{K}_{\text {sat }}$ değerlerini artırdığı ancak zamana bağlı olarak toprakların $\mathrm{K}_{\text {sat }}$ değerlerinin azaldığı anlașılmaktadır. Örnekleme zamanları dikkate alındığında $\mathrm{K}_{\text {sat }}$ en yüksek 4. ayda bozulan saksılardan alınan örneklerde belirlenmiștir. 8. ve 12. aylarda $\mathrm{K}_{\text {sat }}$ 'ın azaldığı belirlenmiștir. Genel olarak killi toprakta $\mathrm{K}_{\text {sat }}$ ölçüm değerleri kumlu topraktan daha düșük bulunmuștur. Diğer taraftan her iki toprakta da uygulanan gidya dozunun artıșına paralel olarak örnekleme gruplarının (4, 8 ve 12. aylar) kendi içerisinde $K_{\text {sat }}$ değerlerinin arttığı ancak zamana bağlı olarak bu değerin azaldığı tespit edilmiștir.

Toprakların doygun koșullardaki hidrolik iletkenlik $\left(\mathrm{K}_{\mathrm{sat}}\right)$ değerlerine ait ANOVA test sonuçlarına göre toprakların $K_{\text {sat }}$ değerlerinde meydana gelen değișim üzerine uygulamaların, toprak çeșidinin ve örnekleme zamanının etkileri istatistiksel açıdan $p<0,001$ düzeyinde önemli bulunmuștur.

Çizelge 10 ve 11 'de $K_{\text {sat }}$ değișkeni için sırasıyla uygulamalara ve zamana ait Duncan test sonuçları verilmiștir. Çizelge 10'a göre G1, G2 ve G1+PAM uygulamaları $K_{\text {sat }}$ üzerine etkinlikleri bakımından istatistiksel olarak aynı bulunmuștur. En düșük $\mathrm{K}_{\text {sat }}$ değeri istatistiksel olarak diğerlerinden farklı olan kontrol saksıları için ve en yüksek $K_{\text {sat }}$ değeri ise G2+PAM uygulaması yapılan saksılar için ölçülmüștür. Örnekleme zamanının $K_{\text {sat }}$ üzerine etkinliği incelendiğinde 4. ve 8. ayın istatistiksel bakımdan aynı, 12. ayın ise ilk iki örnekleme zamanından farklı olduğu sonucu elde edilmiștir (Çizelge 11 ).

Hidrolik iletkenlik toprakların su iletim özelliği olup gözenekliliğin bir fonksiyonudur. Toprakların fiziksel özelliklerinin iyileștirilmes organik materyallerin toprağa ilave edilmes toplam porozitenin artmasını sağlamakta ve sonuçta hidrolik iletkenlik değerinin yükselmesin sağlamaktadır (Boparai vd., 1992). Barzegar vd. (2002), toprağa uyguladıkları çeșitli organik kökenli materyallerin uygulama dozları arttıkça, toprağın hidrolik özelliklerinde kontrole göre 


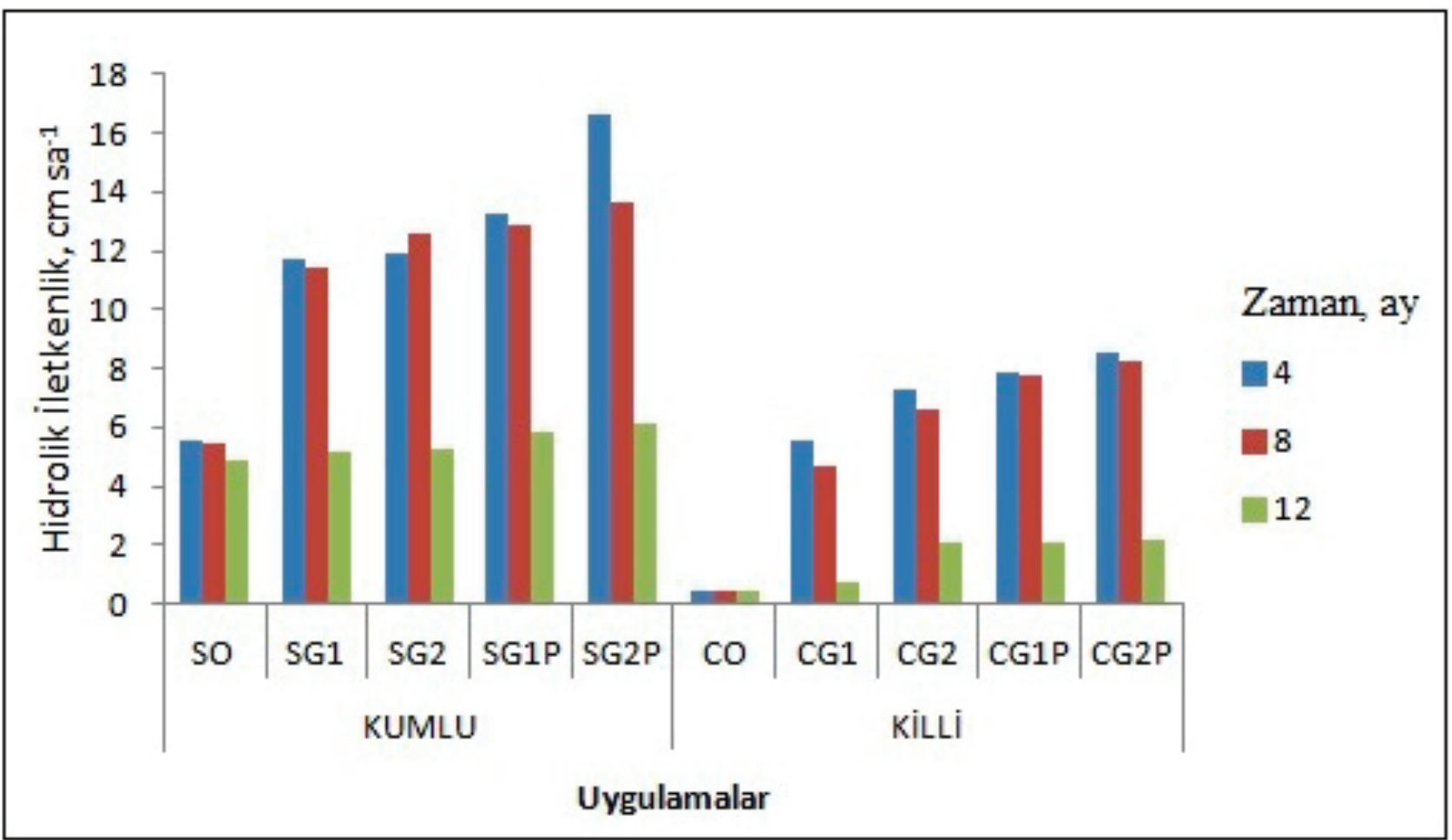

Șekil 4. Uygulamaların toprakların Hidrolik iletkenlik kapsamlarında meydana getirdiği değișimler (SO: Kumlu toprak kontrolü, C0: Killi toprak kontrolü, G1: Gidya birinci doz uygulaması, G2: Gidya ikinci doz uygulaması, G1P: [G1+PAM], G2P: [G2+PAM])

Figure 4. Changes in hydraulic conductivity values of soils with applications (SO: Control for sandy soil, CO: Control for clayey soil, G1: First gyttja dose application, Second gyttja dose application, G1P: [G1+PAM], G2P: [G2+PAM])

Önemli derecede artıș saptamıșlardır. Kum bünyeli topraklara organik madde ilavesi yapıldı̆̆ında, iri boșlukları dolduran humus fraksiyonu, suyu tutabilecek büyüklükteki boșlukların olușmasına katkıda bulunmaktadır. Ağır kil bünyeli topraklarda, mineral taneler arasındaki boșluklar ve aynı zamanda infiltrasyon oranı, hidrolik iletkenlik düșüktür. Organik maddeler taneleri birbirinden uzaklaștırarak ya da teksel kil tanelerini kümelestirmek suretiyle, daha fazla su depolamasına yardım etmektedirler (Lal, 1979). Toprakların fiziksel özelliklerinin iyileștirilmesi için yeșil gübre veya bitki artıklarının toprakla karıștırılması organik maddenin gelișmesine toplam gözenekliliğin artmasına ve sonuçta hidrolik iletkenliğin artmasına katkıda bulunmaktadır (Tirlok vd. 1980; Boparai vd. 1992).

Kumlu ve killi topraklara uygulanan gidya ve PAM'ın ölçülen değișkenlerde kontrole göre meydana getirdiği değișimler çizelge 12'de sunulmuștur. Adı geçen çizelgeye göre düșük doz uygulamalarının bile killi topraklarda $\mathrm{K}_{\text {sat }}$ değerlerini yükseltmede bașarılı olduğu görülmektedir. Genel olarak ise yüksek dozlar ölçülen değișkenlerde oransal olarak daha büyük değișimler meydana getirmekle birlikte Atterberg limitleri ve COLE'deki değișimlerin kumlu topraklarda daha belirgin olduğu sonucuna ulașılmıștır.

Diğer taraftan toprağa uygulanan gidya, özellikle PAM ile birlikte uygulanan yüksek dozlarıyla toprakların doğrusal uzama katsayılarını düșürmüș, hidrolik iletkenliklerini ve atterberg limitleri değerlerini yükseltmiștir. Uygulamaların etkinliği genel olarak zamana bağımlı değișkenlik göstermiștir.

Bu çalıșmadan elde edilen bulgular, organik kökenli toprak düzenleyicilerin polimerler ile birlikte kullanıldıklarında, toprakların fiziksel özelliklerini iyileștirmede sadece organik atık ilavesine göre daha bașarılı olacağını göstermiștir. Konunun daha iyi anlașılması için farklı topraklar üzerinde denemeler yapılmasına ve değișik [organik atık $x$ polimer] kombinasyonlarının denenmelere konu edilmesine gereksinim bulunmaktadır. Bitki yetiștiriciliği altında denemeler yürütülmesi, farklı bitki, toprak ve ekolojik șartlar için en uygun dozun belirlenmesine katkı sağlayacak ve uygulamaların sonuçları tarımsal üretimin ekonomik göstergelerine olumlu yansıyacaktır. Ayrıca parsel koșullarında yürütülecek denemelerin sonuçlarına göre çiftçi düzeyinde tavsiyeler geliștirilmelidir. 
Çizelge 10. Hidrolik iletkenlik değișkeni için uygulamalara ait Duncan testi sonucu

Table 10. Duncan test results for $K_{\text {sat }}$ from applications

\begin{tabular}{|c|c|c|c|}
\hline \multirow{2}{*}{ Uygulama } & \multicolumn{3}{|c|}{$\mathrm{K}_{\mathrm{sat}^{\prime}} \mathrm{cm} \mathrm{sa}^{-1}$ (Alt küme) } \\
\hline & 1 & 2 & 3 \\
\hline Kontrol & $2,8750 \mathrm{c}$ & & \\
\hline G1 & & $6,5467 b$ & \\
\hline G2 & & 7,6183ab & 7,6183ab \\
\hline G1+PAM & & 8,2833ab & 8,2833ab \\
\hline G2+PAM & & & $9,2350 a$ \\
\hline Sig. & 1,000 & 0,085 & 0,107 \\
\hline $\mathrm{HKO}=2,508$ & & & \\
\hline
\end{tabular}

Çizelge 11 . Hidrolik iletkenlik değișkeni İçin örnekleme zamanına ait Duncan testi sonucu

Table 11 . Duncan test results for $K_{\text {sat }}$ from sampling time

\begin{tabular}{|c|c|c|}
\hline \multirow{2}{*}{ Uygulama } & \multicolumn{2}{|c|}{$\mathrm{K}_{\mathrm{sat}} \mathrm{cm} \mathrm{sa}^{-1}$ (Alt küme) } \\
\hline & 1 & 2 \\
\hline 12. ay & $3,4750 \mathrm{~b}$ & \\
\hline 8. ay & & 8,3880a \\
\hline 4. ay & & 8,8720a \\
\hline Sig. & 1,000 & 0,0501 \\
\hline
\end{tabular}

Çizelge 12. Uygulamaların ölçülen değișkenler bakımından topraklarda kontrole göre meydana getirdiği değișimler Table 12. Changes in measured variables with applications according to control

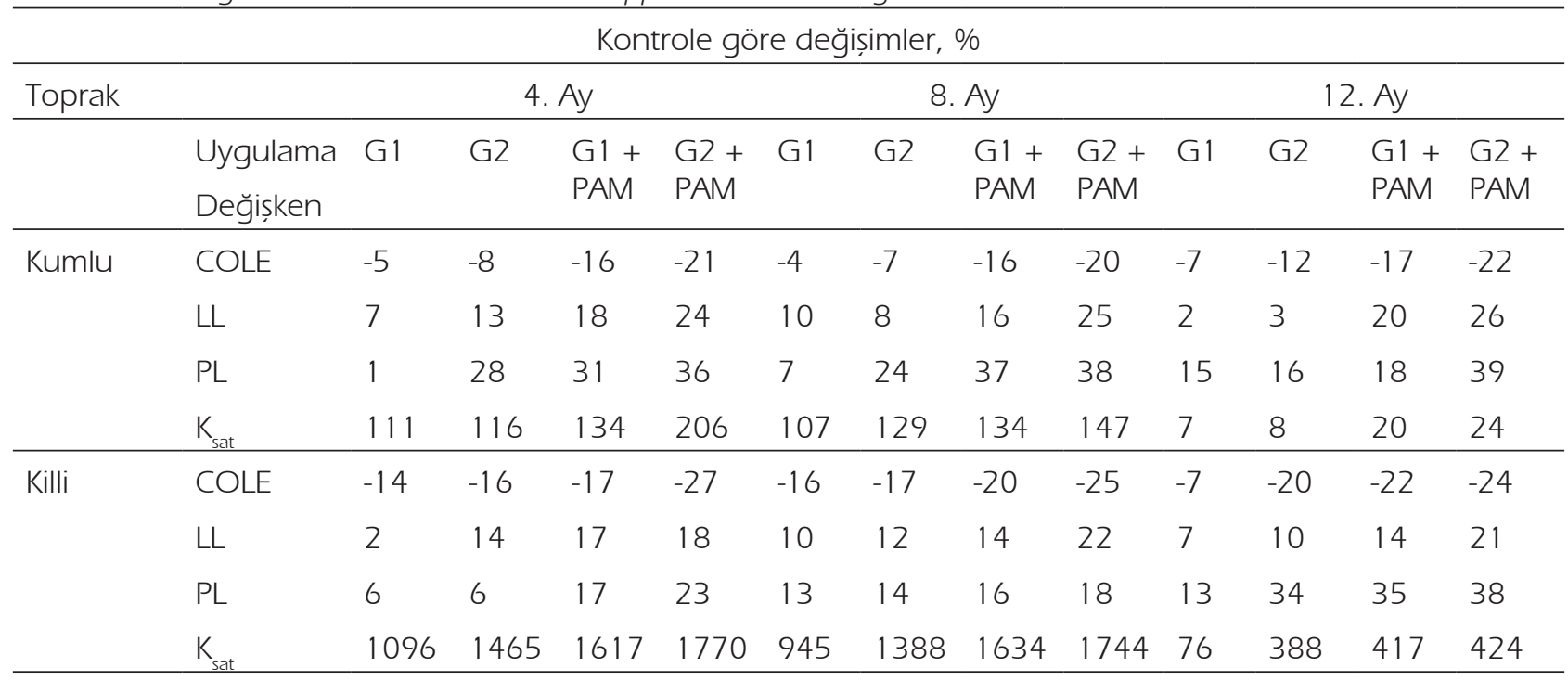

\section{SONUÇLAR}

Bu çalıșmadan elde edilen bulgular, organik kökenlitoprakdüzenleyicilerin polimerlerilebirlikte kullanıldıklarında, toprakların fiziksel özelliklerini iyileștirmede sadece organik atık ilavesine göre daha bașarılı olacağını göstermiștir. Konunun daha iyi anlașılması için farklı topraklar üzerinde denemeler yapılmasına ve değișik [organik atık $x$ polimer] kombinasyonlarının denemelere konu edilmesine gereksinim bulunmaktadır.
Bitki yetiștiriciliği altında denemeler yürütülmesi, farklı bitki, toprak ve ekolojik șartlar için en uygun dozun belirlenmesine katkı sağlayacak ve uygulamaların sonuçları tarımsal üretimin ekonomik göstergelerine olumlu yansıyacaktır. Ayrıca parsel koșullarında yürütülecek denemelerin sonuçlarına göre çiftçi düzeyinde tavsiyeler geliștirilmelidir. 


\section{KAYNAKLAR}

Barzegar A R, Yousefi A, Daryashenas A (2002). The Effect of Addition of Different Amounts and Types of Organic Materials on oil Physical Properties and Yield of wheat. Plant and Soil, 247: 295-301.

Bhuiyan N I (2001). Application of integrated plant nutrition system (IPNS) in agriculture-Bangladesh experiences, Countr paper, September, Bangkok, Thailand, s. 18-20.

Boparai B S, Yadvinder S, Sharma B D (1992). Effect of Green Manure on Pyhsical Properties of Soil and Growth of Rice-wheat and maize-wheat Cropping System. Agrophus, 6: 95-101.

Bryan R B (1992). The influence of some soil conditioners on soil properties: laboratory tests on Kenyan soil samples. Soil Technologies, 5(3): 225-247.

Gezgin S, Dursun N, Hamurcu M, Harmankaya M, Onder M, Sade B, Topal A, Soylu S, Akgun N, Yorgancilar M, Ceyhan E, Ciftci N, Acar B, Gultekin I, Isık Y, Seker C, Babaoğlu M, (2001). Determination of B Contents of Soils in Central Anatolian Cultivated Lands and its Relations Between Soil and Water Characteristics. Boron in Plant and Animal Nutrition. Edited by Goldbach et al., Kluwer Academic/ Plenum Publishers, New York.

Gülser C, Candemir F (2004). Changes in Atterberg Limits with Different Organic Waste Applications. International Soil Congress (ISC) on "Natural Resource Management for Sustainable Development" June 7-10, Erzurum, Turkey.

Hanay A (1992). Çöp kompostu uygulamasının toprakların kıvam limitleri ile bazı strüktür stabilite indekslerine etkisi üzerine bir araștırma. Atatürk Ünv. Zir.Fak. Dergisi, 23(1):29-38.

Head K H (1984). Manual of Soil Laboratory Testing. Vol. 1: Soil Classification and Compaction Tests. ISBN, 0-72731302-9. Biddles Ltd, Guildford, Surrey.

Imbufe A U, Patti A F, Burrow D, Surapaneni A, Jackson W R, Milner A D 2005. Effects of potassium humate on aggregate stability of two soils from Victoria, Australia. Geoderma, 125: 321-330.

Karabulut M, Cosun F (2009). Precipitation trend analyses in Kahramanmaras. Journal of Geographical Science, 7(1): 61-83.

Lal R (1979). Physical Properties and Moisture Retention Characteristics of some Nigerian Soils. Geoderma, 21: 209223.
Lal R, Kimble J M (1997). Conservation tillage for carbon sequestration. Nutrient Cycling in Agroecosystems, 49: 243253

Munsuz N, Akyıldız R (1979). Afșin-Elbistan Bölgesi Linyit Kömürü Havzası Gyttja'larının Bölge Tarım Topraklarının Fiziksel Özelliklerine Etkileri Üzerine Bir Araștırma. TÜBiTAK Projesi Sonuç Raporu, Proje No: TOAG-301, Ankara.

Özdemir N (1998). Toprak Fiziği. Ondokuz Mayıs Üniversitesi Ziraat Fak. Ders Kitabı No:30.

Schafer W M, Singer M J (1976). A new method of measuring shrink-swell potential using soil pastes. Soil Sci. Soc. Am. J, 40: 805-806.

Smith C W, Hadas A, Dan J, Koyumdjısky H (1985). Shrinkage and Atterberg Limits in Relation to Other Properties of Principal Soil Types in Israel. Geoderma, 35: 47-65.

Sojka R E, Lentz R D (1994). Time for yet another look at soil conditioners. Soil Science, 158(4): 233-234.

Sowers G F (1965). Consistency. Methods of Soil Analysis. Part I. American Society of Agronomy, Madison, Wisconsin U.S.A.

Taban S, İbrikçi H, Ortaș I, Kahraman MR, Orhan Y, Güneri A (2005). Türkiye'de gübre üretimi ve Kullanımı, Ankara, s. 17

Tirlok S, Nagarajarao Y, Sadaphal M N (1980). Effect of Legumes on Physical Properties of Soil in Mixed Cropping with Maize. Indian J. Argon, 25(4): 592-599.

Yakupoğlu T, Özdemir N (2006). Erozyona uğramıș topraklarda organik atık uygulamalarının bazı mekaniksel özelliklere etkisi. OMÜ Ziraat Fak. Dergisi, 21 (2):173-178.

Yakupoğlu T, Yilmaz K, Demir, O F (2013). Some physicchemical properties of gyttja as a soil conditioner; removed from Afsin-Elbistan Coal Power Plant basin in Turkey. International Conference on Environmental Science and Technology (ICOEST-2013), Eds: C. Ozdemir, S. Șahinkaya, E. Kalıpcı, M.K. Oden. June 18-21, Urgup, Nevsehir, Turkey. Published on CD.

Yurtseven N (1 984). Deneysel İstatistik Metodlar. Tarım ve Köyișleri Bak. Köy Hizmetleri Gen. Müd. Toprak ve Düzenleyici Araș. Enst. Yayınları, Teknik Yayın No: 56, Ankara. 